University of Nebraska - Lincoln

DigitalCommons@University of Nebraska - Lincoln

$5-8-2021$

Impact Of Coronavirus on the Performance of Library and Information Science Professionals: A Comparative Survey

Subhajit Panda

Chandigarh University, Mohali, Punjab, suvapanda007@gmail.com

Noble .

BLM Girls College, noblewatts058@gmail.com

Follow this and additional works at: https://digitalcommons.unl.edu/libphilprac

Part of the Library and Information Science Commons

Panda, Subhajit and ., Noble, "Impact Of Coronavirus on the Performance of Library and Information Science Professionals: A Comparative Survey" (2021). Library Philosophy and Practice (e-journal). 5649. https://digitalcommons.unl.edu/libphilprac/5649 


\title{
Impact Of Coronavirus on the Performance of Library and Information Science Professionals: A Comparative Survey
}

\author{
Subhajit Panda ${ }^{1}$ and Noble ${ }^{2}$ \\ ${ }^{1}$ Assistant Librarian, University Library, Chandigarh University, Mohali, Punjab, India \\ ${ }^{1}$ Email: subhajit.e9641@cumail.in \\ ${ }^{2}$ Librarian, BLM Girls College, S.B.S. Nagar, Punjab, India \\ ${ }^{2}$ Email: noblewatts058@gmail.com
}

\begin{abstract}
The spread of the deadly disease Coronavirus has had a negative impact on every aspect of human life, including the education sector with no exception. As a preventive measure, Governments worldwide announced lockdown \& closure of the educational institutions, promote a drastic change in the education environment, from conventional classroom-based to online interaction-based. As the second wave of the pandemic strikes India with a tsunami of cases, LIS professionals serve as front-line workers to keep the educational system functioning without interruption. The present study tried to analyze the performance of LIS professionals during this nightmare with thousands of barriers, like limited e-content, internet speed, availability of insufficient devices, inadequate technical knowledge, unfamiliar online learning, lack of social \& personal relationship, financial crisis and physical \& psychological health issues. An online survey was conducted with a sample of $\mathrm{N}=1000$, including 500 library staff \& 500 teaching staff, to find the answers to the research questions. According to the study findings, employees' efficiency, social \& personal relationships and financial situations were negatively influenced by lockdown during COVID-19, although they tried hard to complete their goals and serve the community with authentic information \& knowledge.
\end{abstract}

Keywords: COVID-19, Education Sector, Performance of LIS Professionals, Mental Health, Financial Situation, Employment, Personal Efficiency, Social Relationships

\section{INTRODUCTION}

In India, with its deadly second wave, the COVID-19 (Coronavirus) pandemic provides a clear \& negative effect on humanity, including human lives and knowledge creation, as a standard of human development. It spread its impact on every sector of our society, including the health, economic, social $\&$ educational sector. In this situation, besides the front line and key workers i.e. scientists and healthcare professionals, Library and Information Science (LIS) Professionals are also playing a major role in the adaptation of this "new normal". In the current study, LIS Professionals includes both the Library Staff \& the Teaching Faculty of Library \& Information Science. First, due to changes in the information environment, now its the responsibility of the Library Staff to understand how people search for information, how they perceive its credibility, and how all this relates to their engagement in self-protective behaviours in the crucial period right after the onset of COVID-19 pandemic (Lep et al., 2020). On the other hand, the drastic change of the education system, from conventional classroom-based learning to online interaction-based teaching-learning, affects the Teaching Faculty with a different approach, like lack of digital technology, unavailability of sufficient e-contents, resistance to change etc.

This new normal not only reminded us that change is inevitable, but it also acted as a catalyst for educational institutions to expand and adopt new platforms and techniques (Jena, 2020b). It affects the performance of both the LIS professionals to a great extent. The present study based on a thorough investigation of the impact of this present pandemic on the performance of the LIS professionals that closely relates to the financial, social, mental health issues related to them. 


\section{COVID-19 \& EDUCATIONAL SECTOR}

According to the AISHE web portal, the Indian education sector is one of the world's largest education sector, with more than 1.4 million schools, 993 universities, 39931 colleges, and 10725 stand-alone institutions (AISHE, 2019), and primarily focused on the offline and conventional classroom-based system (Raj, 2020). In India, the second wave of this pandemic brings the nightmare on repeat with a tsunami of cases. The education sectors of India is badly affected by this. And the enforcement of country-wise lockdown creating a very bad effect on the students' life (Jena, 2020b). More than 32 crore learners stopped to move schools/colleges (UNESCO, 2020), all educational activities halted in India. To encounter this critical situation and to safeguard the health of the students \& faculty members, the education system undergoes a drastic change, from conventional classroom-based learning to online interaction-based teaching-learning. Due to lack of digital technology in educational sector their examination process has slow down, causing a delay in new admissions, which has further reversely affected the employment rate. Despite institutions students from rural areas lack knowledge of technology and even don't have a smart phone. Following are the countries with longest duration of school closures, worldwide;

\begin{tabular}{|c|c|c|c|c|}
\hline Rank & Country & $\begin{array}{l}\text { Duration of FULL } \\
\text { closures (in weeks) }\end{array}$ & \begin{tabular}{|c|} 
Duration of PARTIAL \\
closures (in weeks)
\end{tabular} & $\begin{array}{l}\text { Duration of TOTAL } \\
\text { closures (in weeks) }\end{array}$ \\
\hline 1 & Nepal & 26 & 26 & 53 \\
\hline 2 & India & 25 & 27 & 51 \\
\hline 3 & Iraq & 41 & 9 & 50 \\
\hline 3 & Uganda & 37 & 13 & 50 \\
\hline 4 & Bhutan & 20 & 29 & 49 \\
\hline 4 & Eritrea & 14 & 36 & 49 \\
\hline 4 & Eswatini & 28 & 21 & 49 \\
\hline 4 & Palestine & 17 & 32 & 49 \\
\hline 4 & South Sudan & 28 & 21 & 49 \\
\hline 5 & Indonesia & 20 & 27 & 48 \\
\hline 5 & Myanmar & 43 & 5 & 48 \\
\hline 6 & Bangladesh & 47 & 0 & 47 \\
\hline 6 & Bolivia & 39 & 8 & 47 \\
\hline 6 & Rwanda & 27 & 20 & 47 \\
\hline 6 & United States & 0 & 47 & 47 \\
\hline 7 & Angola & 28 & 18 & 46 \\
\hline 7 & Argentina & 22 & 23 & 46 \\
\hline 7 & Costa Rica & 39 & 7 & 46 \\
\hline 7 & Honduras & 37 & 9 & 46 \\
\hline 7 & Panama & 46 & 0 & 46 \\
\hline 8 & El Salvador & 45 & 0 & 45 \\
\hline 8 & Grenada & 12 & 33 & 45 \\
\hline 8 & Guatemala & 33 & 12 & 45 \\
\hline 8 & Guyana & 27 & 18 & 45 \\
\hline 8 & Iran & 16 & 29 & 45 \\
\hline
\end{tabular}




\begin{tabular}{|c|l|c|c|c|}
\hline 8 & Mozambique & 25 & 20 & 45 \\
\hline 9 & Bahrain & 29 & 15 & 44 \\
\hline 9 & Brazil & 38 & 6 & 44 \\
\hline 9 & Chile & 14 & 30 & 44 \\
\hline 9 & Ecuador & 34 & 10 & 44 \\
\hline 9 & Mexico & 44 & 0 & 44 \\
\hline 10 & Colombia & 23 & 20 & 43 \\
\hline 10 & North Macedonia & 20 & 23 & 43 \\
\hline 10 & Sri Lanka & 28 & 15 & 43 \\
\hline
\end{tabular}

(Prepared by: The Future of Learning and Innovation team at UNESCO, Headquarters; Last update: 29 March 2021)

Table 1: Worldwide duration of school closures (Top 10) (in Weeks) (UNESCO, 2020)

\section{LITERATURE REVIEW}

In their chapter, Vaidya \& Ali, (2021) adopted the mixed-method approach to brings out the methods, policies initiated by libraries in 'new normal', and to know the status of library operations during the lockdown. Authors mapped out the experiences of professionals during 'work from home'. Findings of the chapter show that the libraries are struggling to sustain their services to cater to the needs of the university students whose academics has been shoddily affected. Rafiq et al., (2021) explored the university libraries' response during the COVID-19 pandemic and determine their working practices, services patterns, strategies applied, and role-played. A total of 7 university library was selected as study sample and the data was collected through in-depth interview. Ali et al. (2021) aimed to investigate the correlations between changes in sleep pattern, perception of time, and digital media usage in this present pandemic situation. This cross-sectional research took almost two months to complete and received 251 responses via a web-based questionnaire. According to the findings, the sleeping habits of students were the most influenced by the government's lockdown in response to COVID-19. The study of Purwanto et al. (2020) identified the advantages and disadvantages of the 'work from home' situation during pandemic COVID-19, using an approach of qualitative case study with a semi-structured interview. The teaching professionals of an elementary school in Tangerang are the target sample with sample count $N=6$. In another study, Christian et al. (2020) aimed to identify factors in technostress on the teaching performance of 228 lecturers in Jakarta province, Indonesia. The instrument used in this study was a questionnaire and was processed using SPSS 25 software. The findings explained that this techno-complexity factor influenced the online teaching performance of lecturers in the condition of the Covid-19 pandemic. During this pandemic situation, the role of health science librarians was explored by Ali \& Gatiti (2020). Salari et al. (2020) analyzed the existing research works and findings in the Science Direct, Embase, Scopus, PubMed, Web of Science (ISI) and Google Scholar databases, in relation to the prevalence of stress, anxiety and depression in the general population during the COVID-19 pandemic. A meta-analysis was performed using the random effects model was used, and the heterogeneity of studies was investigated using the $\mathrm{I} 2$ index. Moreover, data analysis was conducted using the Comprehensive Meta-Analysis (CMA) software with a total sample size of 9074 .

\section{STUDY RATIONALE}

All of the studies above investigated the impact of COVID-19 on different segments of the population in all possible fields of life, viz health, economic, social \& educational. Whereas, the current research aimed to investigate the performance of LIS professionals (viz, Library staff \& Teaching staff of Library \& Information Science) during this pandemic period. No such research has been conducted yet directing particularly on this area with analyzing actual perception of study sample through online survey. 


\section{OBJECTIVES OF THE STUDY}

After thoroughly analyze the past researches \& determined the study rationale, the present study aimed to determine the impact of COVID-19,

(i) on personal \& professional activities of LIS professionals.

(ii) on mental health and social relationships of LIS professionals.

(iii) on employment and financial situations of LIS professionals.

(iv) on spreading awareness and information \& knowledge sharing.

(v) on the overall performance of LIS professionals.

\section{SCOPE OF THE STUDY}

The present study emphasizes the performance of the LIS professionals in this critical situation of present outbreak of COVID-19 by thoroughly examine its impact in their financial, social and mental health. In this changing situation the LIS professionals face a tough time both in their workplace and in personal life. Considering this fact as a basic, the study tries to cover the situation arises due to this new normal and conduct an online survey among the library professionals of all over the India.

\section{RESEARCH METHODOLOGY}

The study was based upon the factors which impact the performances of LIS professionals e.g. financial, social \& mental conditions that are negatively affected due to this recent outbreak of a global pandemic, COVID-19. To study these factors, the research framework was designed upon a structured research questionnaire created through Google form and circulated online among different social platforms e.g. Facebook, Whatsapp, Telegram, LinkedIn, Academia etc, and also via email to the eminent LIS professionals. Five points scale technique (Strongly Agee-Strongly Disagree) was adopted for collecting data through this questionnaire. It took almost 5 months (from November 20, 2020, to April 15, 2021) and almost 1268 participant took part in this survey. The survey gathered information mainly about the issues which arises during the lockdown and affected the performances of LIS Professionals to a noticeable extent. For sampling, the target group for this study was the Library Staff and the Teaching Faculty of LIS. The sample selection was done after proper analysis of the responses based on adequate, authentic and complete response. From the collected 1268 respondent 1000 were selected as the sample universe $(\mathrm{N})$ for the study and among which 500 were Library Staff and other 500 Teaching Faculty of LIS.

\section{RESEARCH QUESTIONS}

The questionnaire of the survey was designed with 17 research questions covered under 5 distinctly identified groups based on the essence of the impact and characteristics of a particular one.

\begin{tabular}{|c|l|}
\hline SN & Research Question \\
\hline \multicolumn{2}{|c|}{ GR A. Personal and Professional Activities } \\
\hline RQ 1 & I am engaged and interested in my daily activities \\
\hline RQ 2 & $\begin{array}{l}\text { I currently have a good balance between the time I spend at work and the time I have } \\
\text { available for non-work activities }\end{array}$ \\
\hline RQ 3 & At this time, I am meeting the work goals that I have set for myself \\
\hline RQ 4 & I rather became a more active contributor to serve the community \\
\hline
\end{tabular}




\begin{tabular}{|c|l|}
\hline \multicolumn{2}{|c|}{ GR B. Mental health and Social relationships } \\
\hline RQ 5 & $\begin{array}{l}\text { After the inception of the Coronavirus pandemic, I actively avoid people I see } \\
\text { sneezing and coughing }\end{array}$ \\
\hline RQ 6 & $\begin{array}{l}\text { I am afraid that someone in my family might become infected by Coronavirus } \\
\text { (COVID-19) }\end{array}$ \\
\hline RQ 7 & $\begin{array}{l}\text { The work from home situation due to Coronavirus seriously impedes my social } \\
\text { relationships especially my family relationships }\end{array}$ \\
\hline RQ 8 & Uncertainties surrounding Coronavirus (COVID-19) causes me anxiety \\
\hline \multicolumn{1}{|c|}{ GR C. Impact on Employment and Financial Situations } \\
\hline RQ 9 & I have fully/partially lost job-related income due to the Coronavirus (COVID-19) \\
\hline RQ 10 & The Coronavirus (COVID-19) has negatively impacted my financial situation \\
\hline RQ D. Spreading Awareness and Information \& Knowledge Sharing \\
\hline RQ 11 & $\begin{array}{l}\text { I am actively engaged in spreading awareness about the right information, } \\
\text { misinformation, and disinformation } \\
\text { I do not pass misinformation or disinformation spread on social media without } \\
\text { confirming }\end{array}$ \\
\hline RQ 13 & $\begin{array}{l}\text { I lead a purposeful \& meaningful life being a Library and Information Science } \\
\text { Professional }\end{array}$ \\
\hline RQ 14 & $\begin{array}{l}\text { I am actively engaged in educating others through webinars or other means of } \\
\text { e-learning }\end{array}$ \\
\hline RQ 15 & I am more actively engaged in providing E-resources to patrons. \\
\hline
\end{tabular}

Table 2: Survey Questionnaire

\section{DATA ANALYSIS AND INTERPRETATION}

The credibility of the received responses was analyzed and linked not only with lower levels of negative emotional responses but also with higher adherence to much needed self-protective measures, which ultimately ensures the depth of the survey. Among total 1268 responses received in Google Sheet, 1000 were selected as the study sample and analyzed using spreadsheet software (MS Excel) for enhanced visualization. It aims to organize, classify and summarize the data being collected for better comprehension and interpretation leading to understand and explore answers or solutions to the research questions which originally triggered the research.

\section{RESULT \& DISCUSSION}

At first, the analyzed data were divided into 5 groups and further 17 individual research questions and then tabulated as a comparative chart to examine the impact of COVID-19 on the performances between the Library Staff and the Teaching Staff.

(a) GR A. Personal and Professional Activities:

\begin{tabular}{|c|l|c|c|c|c|c|c|}
\hline Res. & Sample & \multicolumn{7}{|c|}{ Responses } \\
\cline { 3 - 8 } Ques. & Category & S.A. & A. & N. & D. & S.D. & Total \\
\hline RQ 1 & $\begin{array}{l}\text { Library } \\
\text { Staff }\end{array}$ & 85 & 112 & 52 & 153 & 98 & 500 \\
\cline { 2 - 8 } & $\begin{array}{l}\text { Teaching } \\
\text { Staff }\end{array}$ & 88 & 124 & 43 & 158 & 87 & 500 \\
\hline RQ 2 & $\begin{array}{l}\text { Library } \\
\text { Staff }\end{array}$ & 64 & 152 & 51 & 177 & 56 & 500 \\
\hline
\end{tabular}




\begin{tabular}{|c|l|c|c|c|c|c|c|}
\hline & $\begin{array}{l}\text { Teaching } \\
\text { Staff }\end{array}$ & 60 & 161 & 96 & 159 & 24 & 500 \\
\hline RQ 3 & $\begin{array}{l}\text { Library } \\
\text { Staff }\end{array}$ & 33 & 54 & 108 & 256 & 49 & 500 \\
\cline { 2 - 7 } & $\begin{array}{l}\text { Teaching } \\
\text { Staff }\end{array}$ & 45 & 91 & 285 & 59 & 20 & 500 \\
\hline RQ 4 & $\begin{array}{l}\text { Library } \\
\text { Staff }\end{array}$ & 25 & 218 & 181 & 36 & 40 & 500 \\
\cline { 2 - 7 } & $\begin{array}{l}\text { Teaching } \\
\text { Staff }\end{array}$ & 50 & 169 & 223 & 26 & 32 & 500 \\
\hline
\end{tabular}

Note: SA- Strongly Agree, A -Agree, N -Neutral, DA- Disagree, SD- Strongly Disagree

Table 2: Responses regarding Personal and Professional Activities

Group A research question (RQ 1-6) particularly belongs to the impact of coronavirus on the personal and professional activities of the library professionals which ultimately affects their performances.

\section{- $\quad$ RQ 1. I am engaged and interested in my daily activities}

During this lockdown \& social distance, there are some factors, such as panic of being infected with the pandemic, fear of job loss \& economic survival, a decline in mental health, etc., that affect our engagement and interest in daily activities. RQ 1 aims to collect information about how these effects have influenced LIS practitioners (including library personnel and teaching faculty) in their everyday lives.

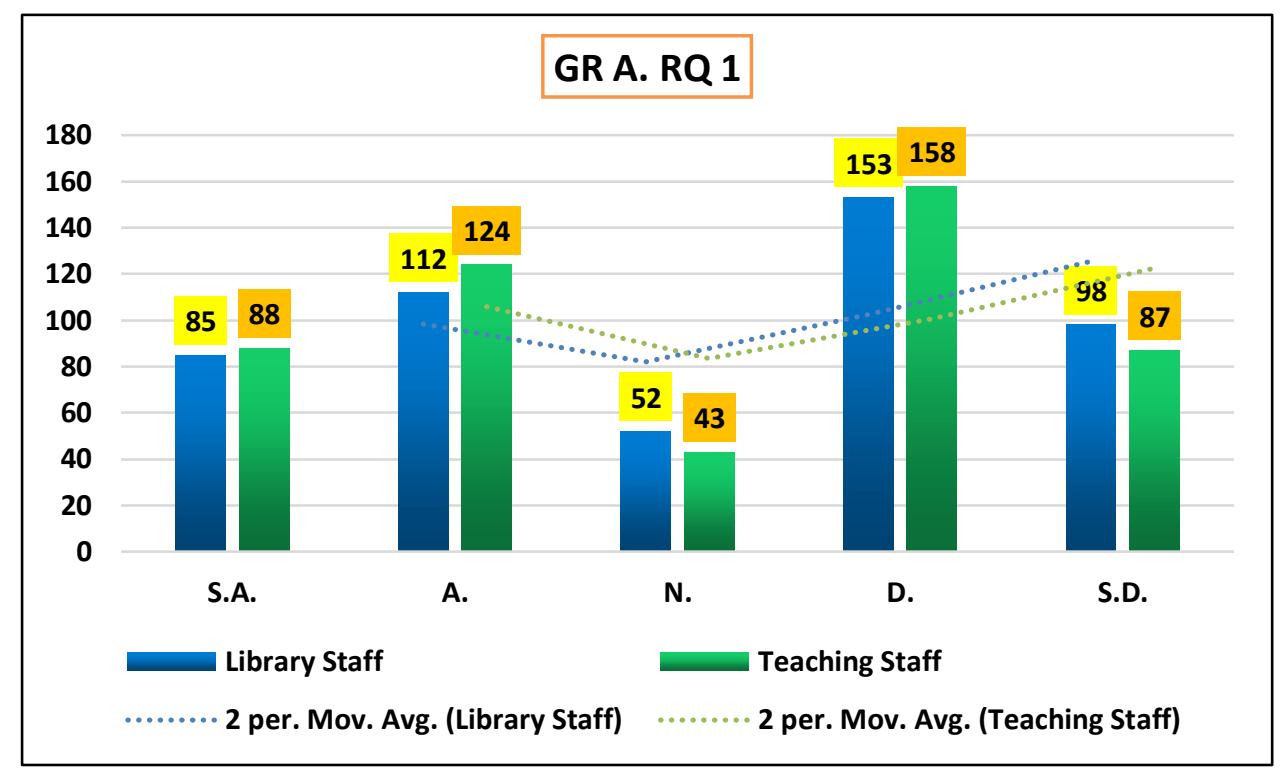

Note: SA- Strongly Agree, A -Agree, N-Neutral, DA- Disagree, SD- Strongly Disagree

Figure 1: Engagement and Interest about Daily Activities

After evaluating the result on five-point Likert Scale it can be shown (Table $2 \&$ Figure 1) that, out of the 500 respondents, $39.4 \%$ (197) of library staff \& $42.4 \%$ (212) of teaching staff respond as agreeing or strongly agreeing, $10.4 \%$ (52) of library staff \& $8.6 \%$ (43) of teaching staff are neutral and $50.2 \%$ (251) of library staff \& 49\% (245) of teaching staff respond as disagreeing or strongly disagreeing with the RQ 1 . It indicates, though a notable percentage of the library \& teaching staff enthusiastically engaged themselves in their daily activities and fulfilled their professional responsibility, the majority effects negatively due to this COVID-19 outbreak \& lockdown position.

- RQ 2. I currently have a good balance between the time I spend at work and the time I have available for non-work activities 
Due to the current pandemic situation now both the library \& teaching staff doing their professional work from home. The library staffs provide e-learning material to the students, remote access to publishers database to the faculty member \& researcher, also conduct virtual orientation tour to the library and provide virtual reference service to the new joining. On the other side, the teaching staff providing online lectures to the students via screen sharing platform like FreeConferenceCall, Google Meet, Zoom, Cisco Webex etc. The main objective of RQ 2 is to know whether in this 'work from home' system there is a good balance between the time available for work and non-work activities.

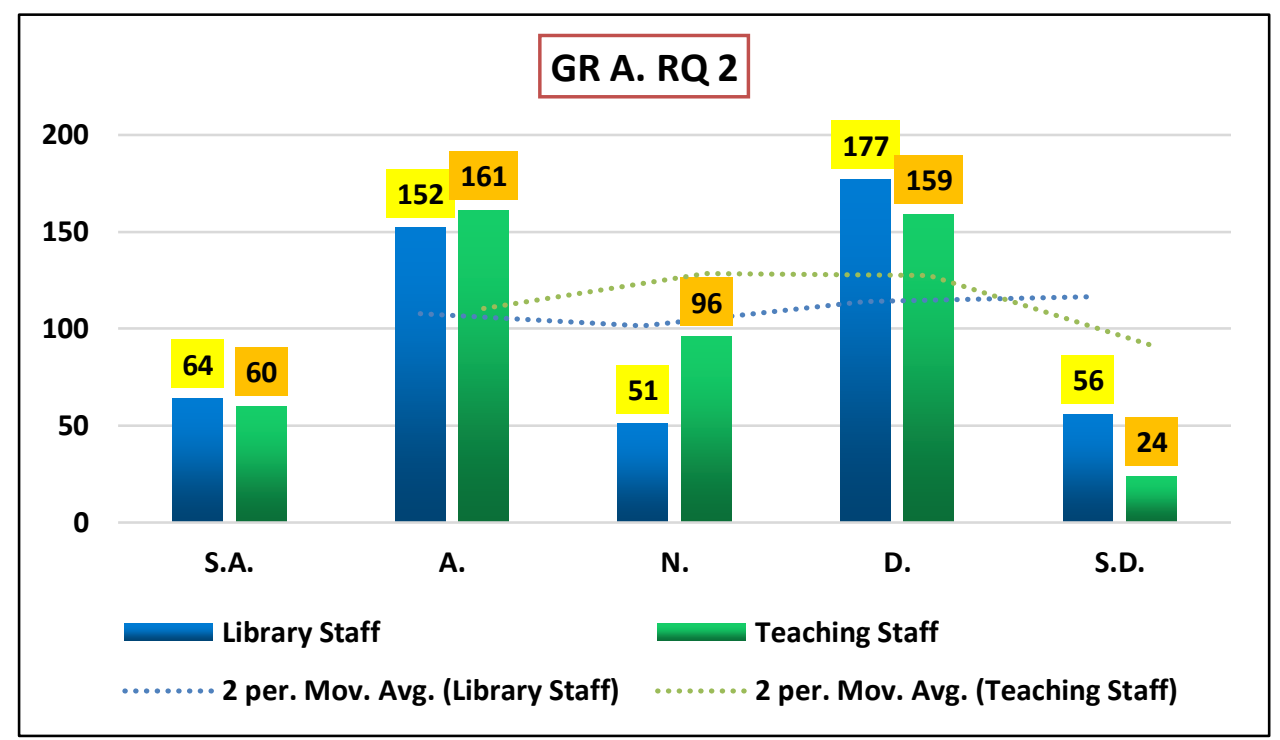

Note: SA- Strongly Agree, A -Agree, N-Neutral, DA- Disagree, SD- strongly Disagree Figure 2: Balance between Work- \& Non-Work Activities

With analyzing the data from Table $2 \&$ Figure 2 it can be identified that according to the institution type \& work culture, some portion of the respondents successfully overcome the situation and manage to maintain a good balance between the time they spend at work and non-work activities, but some others can't do so. Of the total 500 respondents, 216 (43.2\%) library staff \& 221 (44.2\%) teaching staff are either agree or strongly agree with RQ 2. Whereas, $233(46.6 \%)$ library staff \& $183(36.6 \%)$ teaching staff disagree or strongly disagree with RQ 2 and only 51 library staff \& 96 teaching staff being neutral for the same. The response to this research question distributed among all possible field and don't follow any particular trend.

\section{- RQ 3. At this time, I am meeting the work goals that I have set for myself}

Both the library professional and the teaching staff set their work goals for a short time or long term basis as per the necessity. Such work priorities are either library facilities, budget allocation, procurement, maintenance, etc., or lectures, course syllabus, assignments \& assessments. In RQ 3, "at this time" refers to the present situation of "new normal". Because of the present situation, the way to achieve these work goals has now changed and some problems \& difficulties inevitably arise to implement this. RQ 3 explores how many job targets can be achieved by library practitioners and teaching personnel while facing these difficulties. 


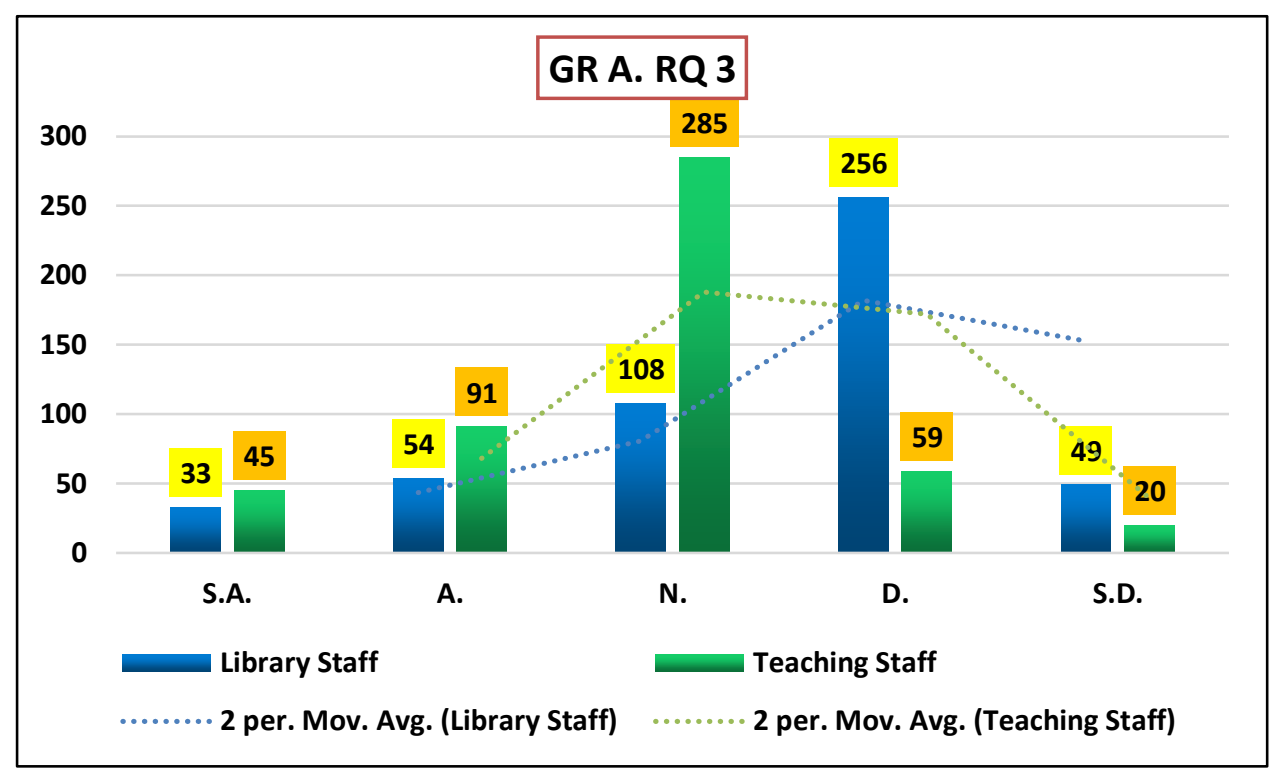

Note: SA- Strongly Agree, A -Agree, N -Neutral, DA- Disagree, SD- strongly Disagree Figure 3: Meet the Already Set Work Goals

It can be observed from Table 2 and Figure 3 that the majority of the library staff choose to disagree or strongly disagree (305 or 61\%) in response RQ3, rather than teaching staff, prefer neutral (285 or $57 \%$ ) for the same. Overall, the responses of RQ3 indicates that for library staff, the trend goes from neutral to disagree \& strongly disagree side while for teaching staff, the trend steeps from strongly agree or agree to the neutral side.

\section{- $\quad$ RQ 4. I rather became a more active contributor to serve the community}

Rather than getting demotivate, depressed, or panic due to this current pandemic situation, how the library professionals provide their daily services as a contributor to the community is the main focus of this research question. This contribution includes, providing daily library services, adequate documents; distribute right information; spreading awareness services (through webinars \& other outreach activities); prevent from spreading fake news \& misinformation etc.

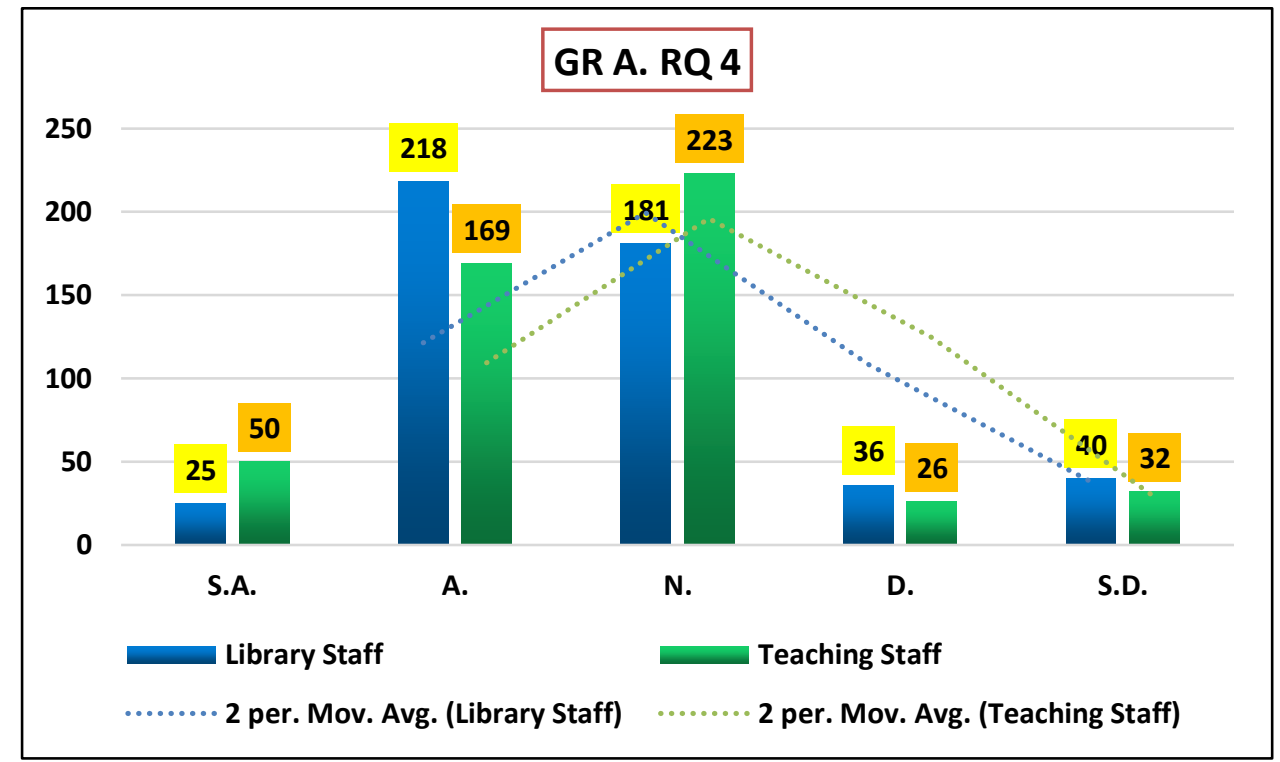

Note: SA- Strongly Agree, A -Agree, N -Neutral, DA- Disagree, SD- strongly Disagree

Figure 4. Active Contributor to Serve the Community 
Statistics from the Figure 4 and Table 2 indicates that majority of the library and teaching staff are either agree (43.6\% library staff \& 33.8\% teaching staff) or neutral (36.2\% library staff \& $44.6 \%$ teaching staff) in response to RQ4. Besides, only 5\% (25) library staff \& $10 \%$ (50) teaching staff strongly agree to become an active \& responsible contributor to serve the community, while $15.2 \%$ (76) library staff \& $11.6 \%$ (58) teaching staff disagree or strongly disagree for the same.

\section{(b) GR B. Mental health and Social relationships:}

Group B research questions ( $R Q 5-8)$ particularly belongs to the impact of coronavirus on the mental health and social relationships of the library professionals which may negatively impact their performances.

\begin{tabular}{|c|c|c|c|c|c|c|c|}
\hline \multirow{2}{*}{$\begin{array}{l}\text { Res. } \\
\text { Ques. }\end{array}$} & \multirow{2}{*}{$\begin{array}{l}\text { Sample } \\
\text { Category }\end{array}$} & \multicolumn{6}{|c|}{ Responses } \\
\hline & & S.A. & A. & N. & D. & S.D. & Total \\
\hline \multirow[t]{2}{*}{ RQ 5} & $\begin{array}{l}\text { Library } \\
\text { Staff }\end{array}$ & 252 & 139 & 65 & 36 & 8 & 500 \\
\hline & $\begin{array}{l}\text { Teaching } \\
\text { Staff }\end{array}$ & 269 & 152 & 41 & 24 & 12 & 500 \\
\hline \multirow[t]{2}{*}{ RQ 6} & $\begin{array}{l}\text { Library } \\
\text { Staff }\end{array}$ & 149 & 175 & 64 & 31 & 81 & 500 \\
\hline & $\begin{array}{l}\text { Teaching } \\
\text { Staff }\end{array}$ & 148 & 204 & 68 & 36 & 44 & 500 \\
\hline \multirow[t]{2}{*}{ RQ 7} & $\begin{array}{l}\text { Library } \\
\text { Staff }\end{array}$ & 95 & 139 & 96 & 79 & 91 & 500 \\
\hline & $\begin{array}{l}\text { Teaching } \\
\text { Staff }\end{array}$ & 124 & 180 & 96 & 58 & 42 & 500 \\
\hline \multirow[t]{2}{*}{ RQ 8} & $\begin{array}{l}\text { Library } \\
\text { Staff }\end{array}$ & 133 & 157 & 95 & 40 & 75 & 500 \\
\hline & $\begin{array}{l}\text { Teaching } \\
\text { Staff }\end{array}$ & 90 & 118 & 131 & 72 & 89 & 500 \\
\hline
\end{tabular}

Note: SA- Strongly Agree, A -Agree, N -Neutral, DA- Disagree, SD- strongly Disagree

Table 3: Responses regarding Mental Health \& Social Relationships

- RQ 5. After the inception of the Coronavirus pandemic, I actively avoid people I see sneezing and coughing

Due to a certain weather change in different parts of India, sneezing \& coughing is a commonly visible problem among people when we travel through public transport. But after the outcome of this new pandemic COVID-19, this common disease becomes a new threat to everyone as these are also symptoms of Coronavirus infection. This question tries to find out self-awareness \& precautions taken by library professionals to protect them from getting infected. 


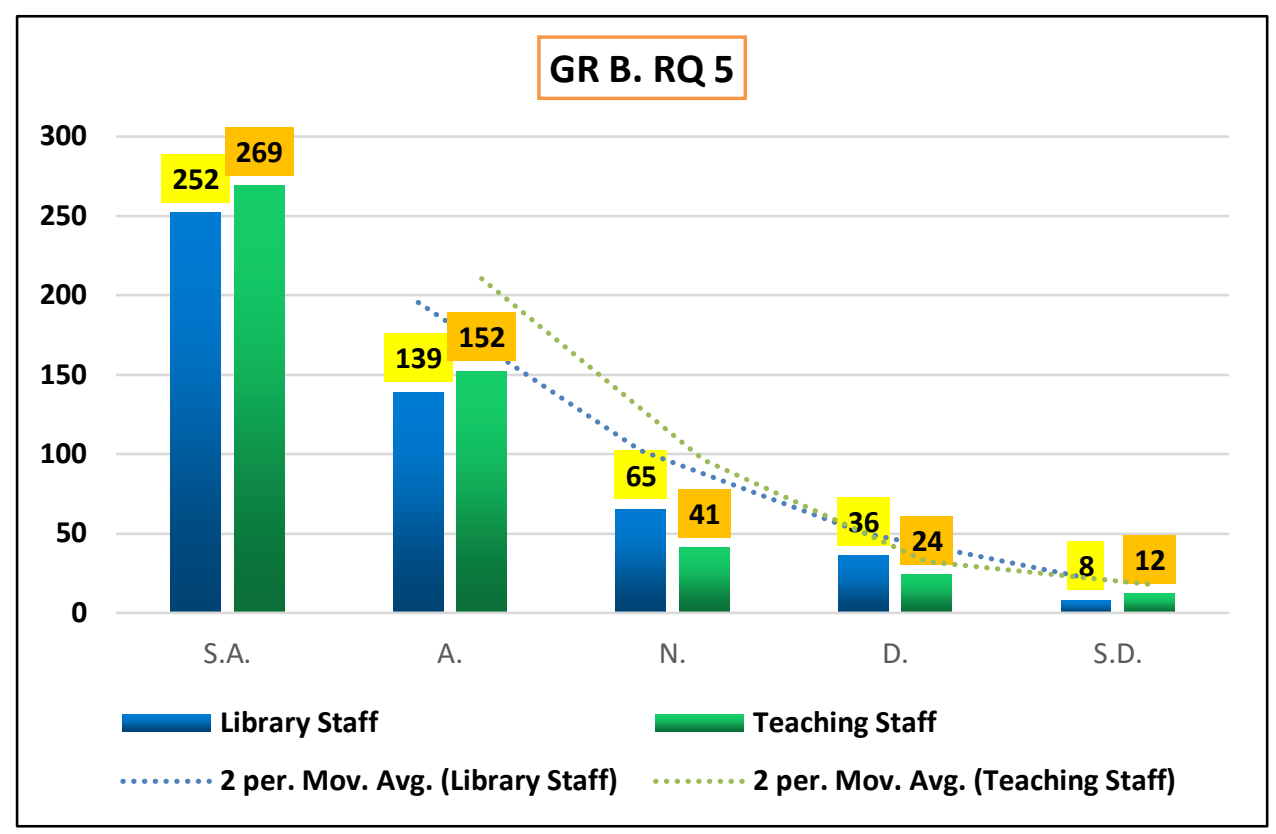

Note: SA- Strongly Agree, A -Agree, N -Neutral, DA- Disagree, SD- strongly Disagree

Figure 5: Avoiding People with Sneezing \& Coughing

According to the responses to RQ 5 (figure 5 \& table 3), the majority of library staff (391/78.2\%) and teaching staff $(421 / 84.2 \%)$ are aware of and responsible for their wellbeing. They take appropriate care and try to keep a safe distance from people who exhibit typical Coronavirus symptoms such as coughing \& sneezing. While, $13 \%$ (65) of library staff \& $8 \%$ (41) of teaching staff somewhat try to take prevention, but $8.8 \%$ (44) library staff $\& 7.2 \%$ (36) teaching staff are carelessly responses that they not serious at all about maintaining distance $\&$ health care precautions.

\section{- RQ 6. I am afraid that someone in my family might become infected by Coronavirus (COVID-19)}

Fear is an adaptive response in the presence of danger. However, when the threat is uncertain and continuous, as in the current coronavirus disease (COVID-19) pandemic, fear can become chronic and burdensome (Mertens et al., 2020). Both library \& teaching personnel come into contact with a large number of people at their workplace, which raises the fear of being infected with COVID-19. It also increases the risk for their family \& surroundings.

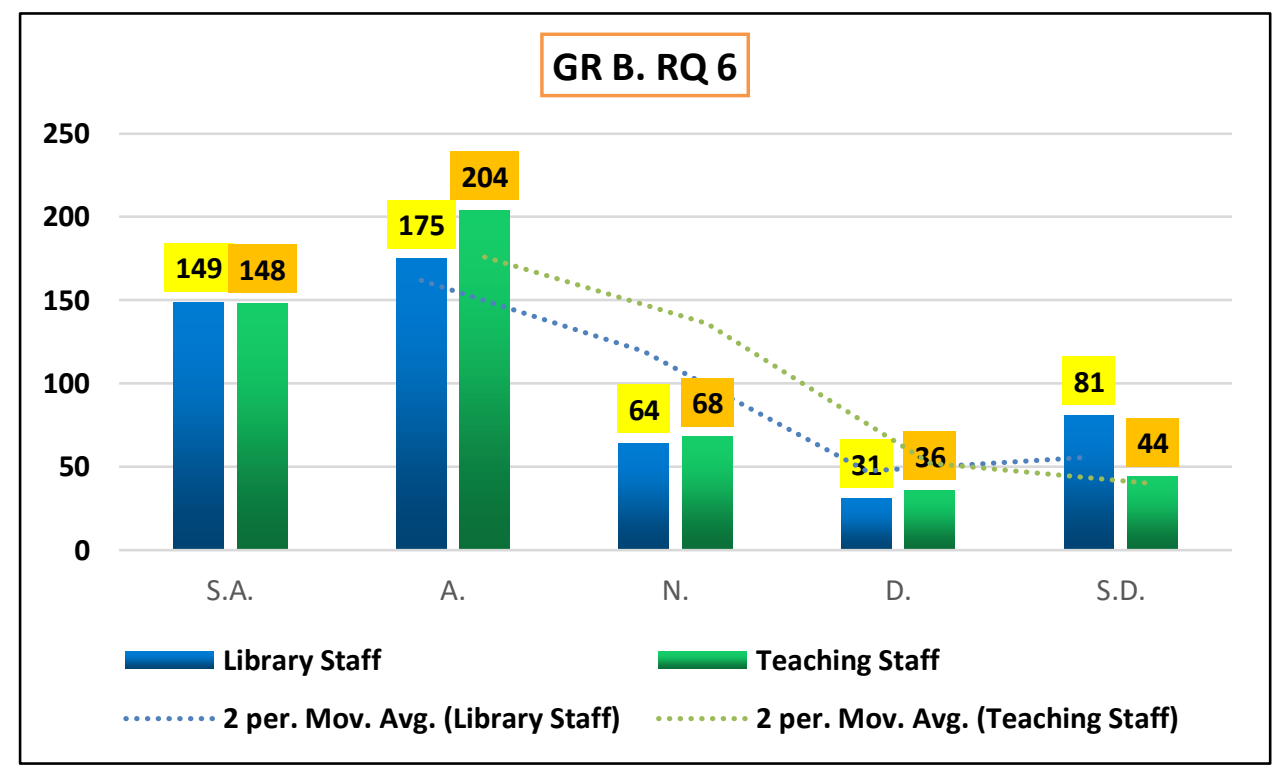

Note: SA- Strongly Agree, A -Agree, N -Neutral, DA- Disagree, SD- strongly Disagree 


\section{Figure 6: Fear of Infection \& Family Safety}

It can be observed from figure 6 that the majority of the library staff (324/64.8\%) and teaching staff $(352 / 70.4 \%)$ are afraid that their family might get infected by COVID-19. On the other hand, $12.8 \%$ (64) of library staff and $13.6 \%$ (68) of teaching staff try to be positive in this challenging situation. And most surprisingly, $22.4 \%$ (112) of library staff \& $16 \%$ (80) of teaching staff are not at all getting afraid of being infected $\&$ its spreading at home.

\section{- $\quad$ RQ 7. The work from home situation due to Coronavirus lockdown seriously impedes my social relationships especially my family relationships}

Working from home might not be suited to everyone's personality or ability. Some employees might prefer the routine and structure that working in an office environment provides them. Some staff may prefer personal interaction with colleagues and also find face-to-face guidance with their manager extremely beneficial in helping them complete tasks and achieve their goals (Migrator, 2000). Besides some potential benefits, work from home has drastically caused trouble in the social \& personal life of some library \& teaching personal. Factors like no routine working time, information security risk, home distraction, lack of knowledge \& habit of using technology are ultimately decreasing in the family hours. And as a result, impeding personal \& social relationships among people.

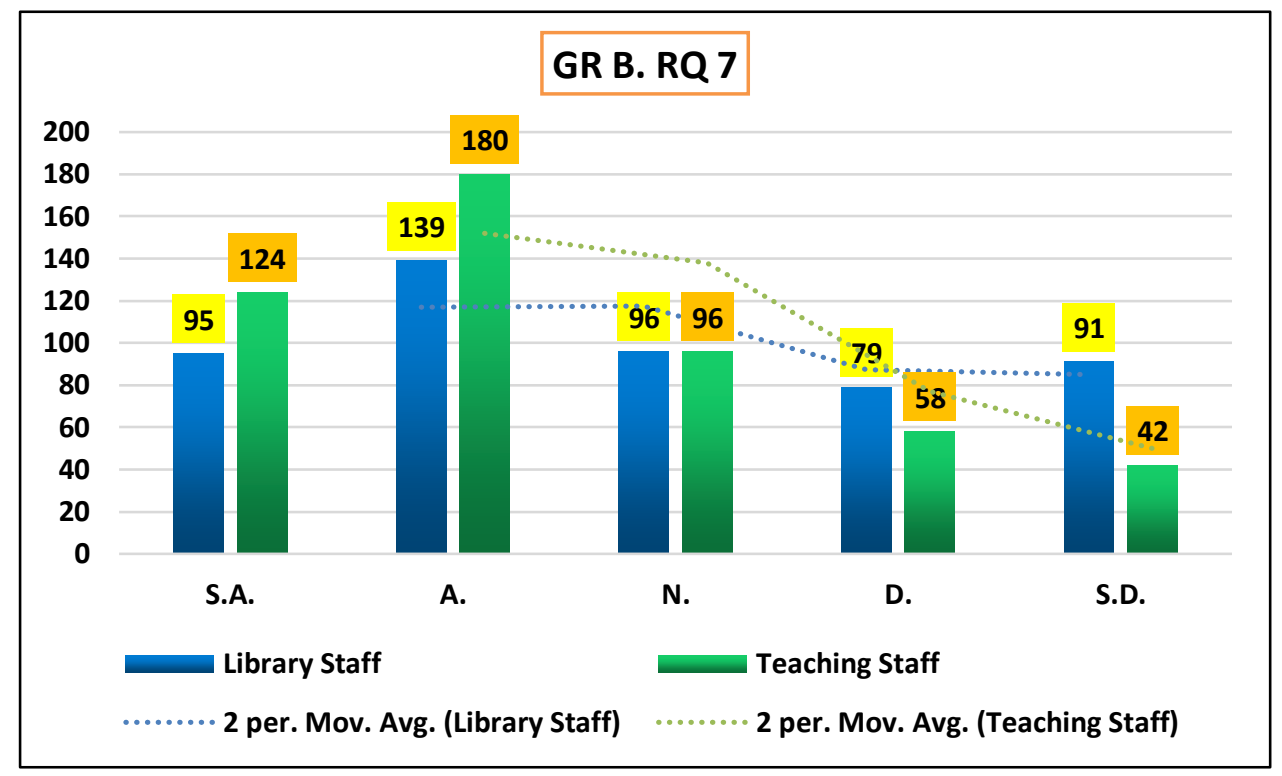

Note: SA- Strongly Agree, A -Agree, N -Neutral, DA- Disagree, SD- strongly Disagree

Figure 7: Work-from-Home \& Social Relationship

Figure $7 \&$ Table 3 gives information about the library professionals' responses against RQ 7. Of the total 500 respondents, $46.8 \%$ (234) library staff \& 60.8\% (304) agree or strongly agree that the work-from-home situation during COVID-19 lockdown affects their social \& family life negatively. Whereas, $19.2 \%$ of library \& teaching staff succeed to balance between positive \& negative impact, and $34 \%$ (170) library staff \& 20\% (100) of teaching staff can't identify any such effect because of lockdown \& remote working condition. This data shows that the effect of work from home is more on teaching staff in comparison with the library staff.

\section{- RQ 8. Uncertainties surrounding Coronavirus (COVID-19) causes me anxiety}

The current COVID-19 pandemic has heightened uncertainty over the economy, employment, finances, relationships, and of course, physical and mental health (Robinson \& Smith, 2020). People are becoming patient of anxiety due to insecurities about improper medication facility, lack of proper COVID-19 testing, the uncertainty of vaccination, extending lockdown period, increasing remote 
working time, lack of socialization, and uncertainty of income \& job-related issues. These insecurities have increased the need for psychiatrists, psychologist \& counsellor.

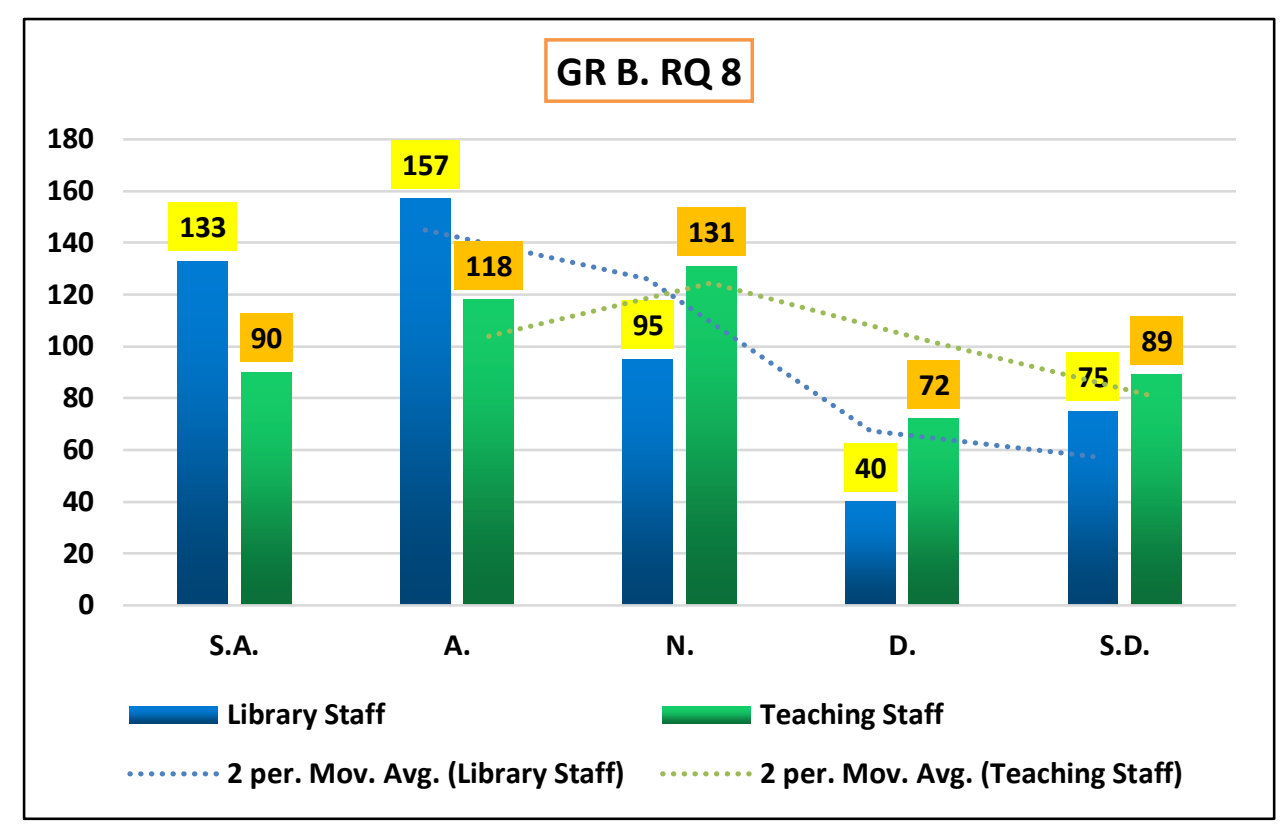

Note: SA- Strongly Agree, A -Agree, N -Neutral, DA- Disagree, SD- strongly Disagree

Figure 8: Anxiety because of Surrounding Situation

Figure 8 depicts information about the responses of the library \& teaching staffs on behalf of RQ 8 . The result reveals that the majority of the library staff $(290 / 58 \%)$ \& teaching staff $(208 / 41.6 \%)$ suffers from anxiety due to uncertain surroundings during COVID-19. A notable percentage of library professionals (viz. 19\% (95) of library staff \& $26.2 \%$ (131) of the teaching staff) is somehow a victim of minor anxiety but successfully recover it. Whereas $23 \%$ (115) of library staff and $32.2 \%$ (161) of teaching staff demand that they don't feel any kind of anxiety in this situation. Also, it can be concluded from the study that library staff suffers more from anxiety may be due to a lack of regular communication and interaction with students and other patrons.

\section{(c) GR C. Impact on Employment and Financial Situations:}

Covid-19 has impacted employment and financial situations of LIS professionals negatively. Due to lockdown and shut down of educational institutions workers are either facing cut in their salary or lost their jobs for this lockdown period, which has increased unemployment. On the other hand rise in expenditure on precautionary material like masks, gloves, sanitizer etc. Use of personal transport instead of public transport etc. has resulted in worsening financial situations.

\begin{tabular}{|c|c|c|c|c|c|c|c|}
\hline \multirow{2}{*}{$\begin{array}{l}\text { Res. } \\
\text { Ques. }\end{array}$} & \multirow{2}{*}{$\begin{array}{l}\text { Sample } \\
\text { Category }\end{array}$} & \multicolumn{6}{|c|}{ Responses } \\
\hline & & S.A. & A. & N. & D. & S.D. & Total \\
\hline \multirow[t]{2}{*}{ RQ 9} & $\begin{array}{l}\text { Library } \\
\text { Staff }\end{array}$ & 149 & 49 & 63 & 41 & 198 & 500 \\
\hline & $\begin{array}{l}\text { Teaching } \\
\text { Staff }\end{array}$ & 109 & 36 & 68 & 40 & 247 & 500 \\
\hline \multirow[t]{2}{*}{ RQ 10} & $\begin{array}{l}\text { Library } \\
\text { Staff }\end{array}$ & 145 & 92 & 116 & 95 & 52 & 500 \\
\hline & $\begin{array}{l}\text { Teaching } \\
\text { Staff }\end{array}$ & 108 & 89 & 133 & 104 & 66 & 500 \\
\hline
\end{tabular}

Note: SA- Strongly Agree, A -Agree, N -Neutral, DA- Disagree, SD- strongly Disagree

Table 5: Responses regarding Impact on Employment and Financial Situations

- $\quad$ RQ 9. I have fully/partially lost job-related income due to the Coronavirus (COVID-19) 
Shutting down educational facilities during the lockdown, a drop in student numbers, UGC guidelines on remote learning, and other economic factors have led to complete or partial pay deductions, decreasing contract renewals, or permanent work dismissal as a means of balancing the budget. As a result, many LIS professionals have partially or fully lost job leads increased their hardship in terms of income and remittances (Guha et al., 2020).

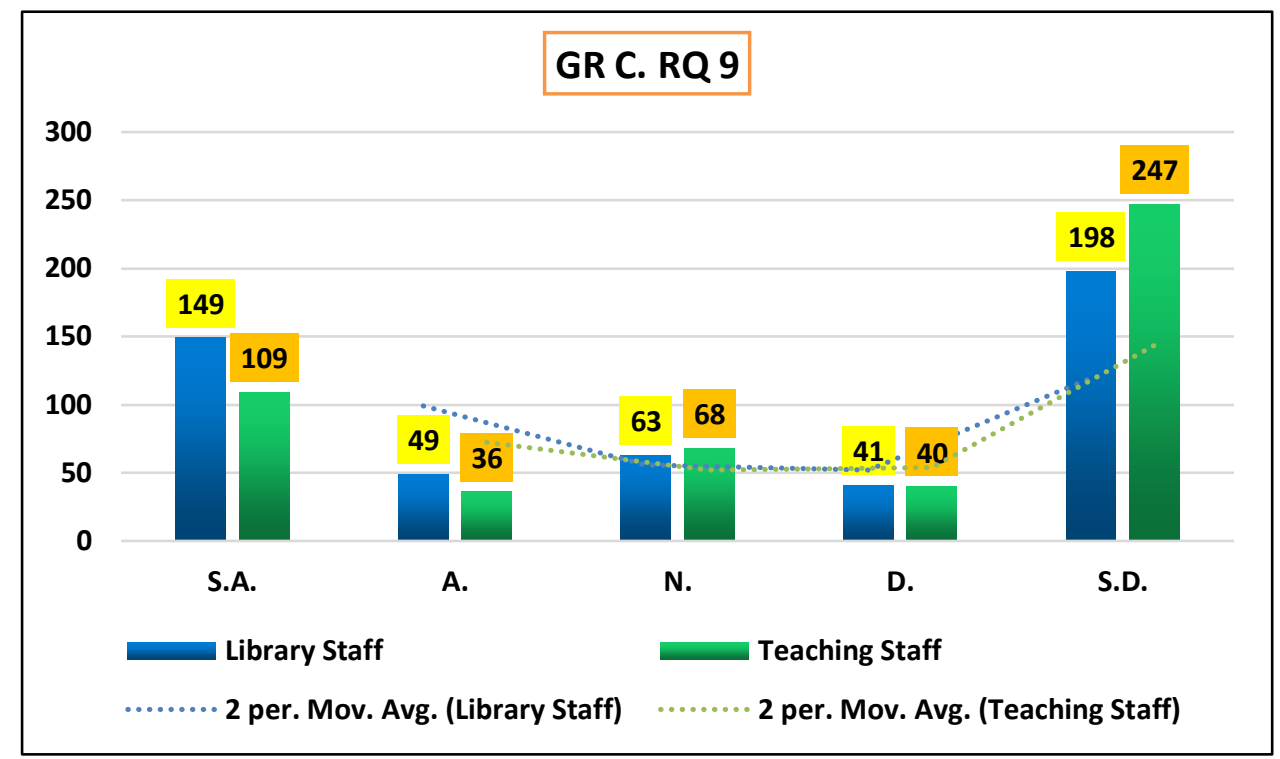

Note: SA- Strongly Agree, A -Agree, N -Neutral, DA- Disagree, SD- strongly Disagree Figure 9: Pandemic effect on Job Related Income

Above figure 9 illustrates that out of 500 sample respondents, 39.7\% (198) of library staff and $29 \%$ (145) of teaching staff agreed or strongly agreed that that faced huge financial problem from job-related to income due to Coronavirus lockdown. On another side, $12.6 \%$ (63) of library staff \& $13.6 \%$ (68) of teaching staff suffers neutrally but, with a majority, $47.8 \%$ (239) of library staff \& $57.4 \%$ (287) of teaching staff identify no such effect in their job-related income.

\section{- RQ 10. The Coronavirus (COVID-19) has negatively impacted my financial situation.}

Due to partially/fully lost job-related revenue, expanding the lockdown duration, rising expenditure, loss of job income of family member and declining savings have harmed the overall financial situation of working LIS professionals. Now it is also felt on everyone's household budgets. 


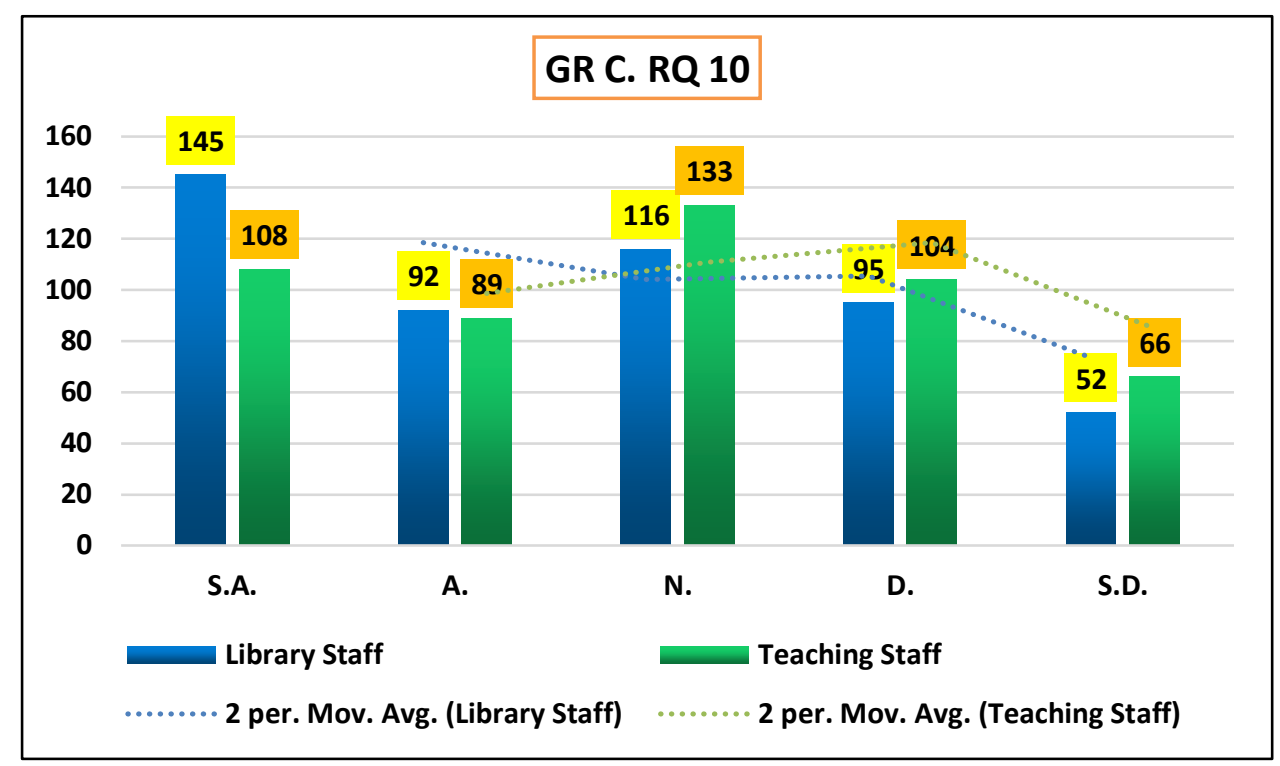

Note: SA- Strongly Agree, A -Agree, N -Neutral, DA- Disagree, SD- strongly Disagree

Figure 10: Pandemic \& its Negative Impact on Financial Situation

The response under RQ 10 demonstrate in Figure 10 as 47.4\% (237) of library staff \& 39.4\% (197) of teaching staff believe that the present outbreak of the Coronavirus pandemic harms their overall financial situation. But in contrast, some of LIS Professionals, viz, 29.4\% (147) of library staff \& 34\% (170) of teaching staff can't measure any sort of financial loss in this situation, whereas, $23.2 \%$ (116) of library staff $\& 26.6 \%$ (133) of teaching staff remains in a neutral position.

\section{(d) GR D. Spreading Awareness and Information \& Knowledge Sharing:}

GR D. is related to spreading awareness and information and also about how LIS professionals are playing role in knowledge sharing. LIS professionals are playing an important role in spreading awareness about COVID-19, about authentic sources of information about COVID-19, etc. They are also more actively engaged in providing e-resources to students as well staff members.

\begin{tabular}{|c|c|c|c|c|c|c|c|}
\hline \multirow{2}{*}{$\begin{array}{l}\text { Res. } \\
\text { Ques. }\end{array}$} & \multirow{2}{*}{$\begin{array}{l}\text { Sample } \\
\text { Category }\end{array}$} & \multicolumn{6}{|c|}{ Responses } \\
\hline & & S.A. & A. & $\mathbf{N}$. & D. & S.D. & Total \\
\hline \multirow[t]{2}{*}{ RQ 11} & $\begin{array}{l}\text { Library } \\
\text { Staff }\end{array}$ & 177 & 163 & 68 & 55 & 37 & 500 \\
\hline & $\begin{array}{l}\text { Teaching } \\
\text { Staff }\end{array}$ & 164 & 164 & 76 & 44 & 52 & 500 \\
\hline \multirow[t]{2}{*}{ RQ 12} & $\begin{array}{l}\text { Library } \\
\text { Staff }\end{array}$ & 293 & 134 & 51 & 17 & 05 & 500 \\
\hline & $\begin{array}{l}\text { Teaching } \\
\text { Staff }\end{array}$ & 288 & 140 & 46 & 20 & 06 & 500 \\
\hline \multirow[t]{2}{*}{ RQ 13} & $\begin{array}{l}\text { Library } \\
\text { Staff }\end{array}$ & 224 & 144 & 81 & 32 & 19 & 500 \\
\hline & $\begin{array}{l}\text { Teaching } \\
\text { Staff }\end{array}$ & 191 & 120 & 132 & 25 & 32 & 500 \\
\hline \multirow[t]{2}{*}{ RQ 14} & $\begin{array}{l}\text { Library } \\
\text { Staff }\end{array}$ & 193 & 160 & 40 & 59 & 48 & 500 \\
\hline & $\begin{array}{l}\text { Teaching } \\
\text { Staff }\end{array}$ & 247 & 148 & 29 & 35 & 41 & 500 \\
\hline \multirow[t]{2}{*}{ RQ 15} & $\begin{array}{l}\text { Library } \\
\text { Staff }\end{array}$ & 232 & 164 & 56 & 12 & 36 & 500 \\
\hline & Teaching & 220 & 156 & 71 & 29 & 24 & 500 \\
\hline
\end{tabular}




\begin{tabular}{|l|l|l|l|l|l|}
\hline & Staff & & & & \\
\end{tabular}

Table 6: Responses regarding Spreading Awareness and Information \& Knowledge Sharing

- RQ 11. I am actively engaged in spreading awareness about the right information, misinformation, and disinformation

In the world of modern ICT, exponential growth of information promoted the increasingly spread of misinformation \& disinformation over internet. Library professionals (both teaching \& library staff), as an information moderator (in the right way to the right person \& in the right time) can contribute his best to stop misinformation from spreading and aware people about the same.

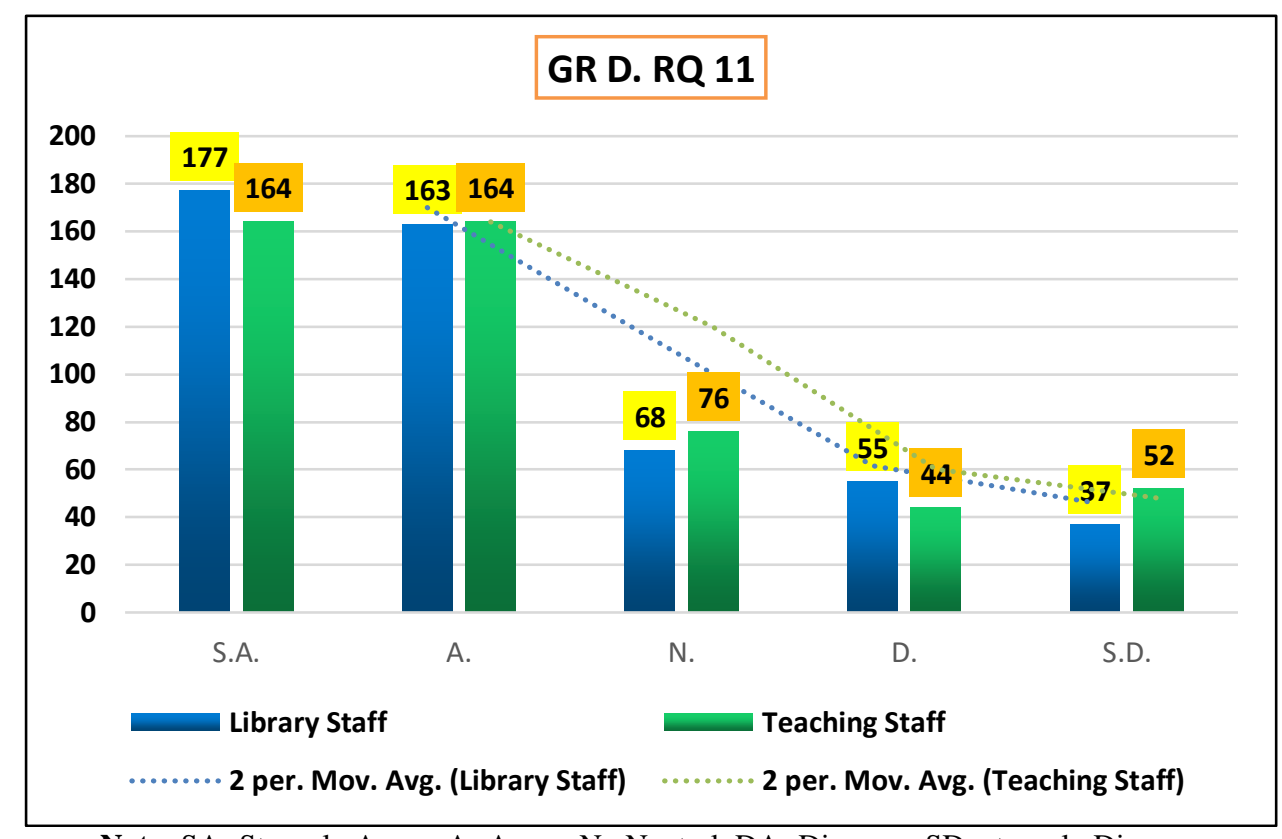

Note: SA- Strongly Agree, A -Agree, N -Neutral, DA- Disagree, SD- strongly Disagree

Figure 11: Spreading Awareness about the Right information, Misinformation, and Disinformation

Figure 11 and Table 6 displays the responses of library \& teaching staff on behalf of RQ 11 . It indicates that almost $68 \%$ (340) of the library staff \& $65.6 \%$ (328) of the teaching staff agreed or strongly agreed that they are actively engaged themselves to aware people about the misinformation \& disinformation spread over the internet, as well as refer them authenticate sources to satisfy their desire. Although, only $13.6 \%$ (68) library staff \& $15.2 \%$ (76) of teaching staff find themself in a neutral position and $18.4 \%$ (92) of library staff \& $19.2 \%$ (96) of teaching faculty can't participate successfully.

\section{- RQ 12. I do not pass misinformation or disinformation spread on social media without confirming}

During COVID-19, some of our incompetence \& ill practices were responsible for the dissemination of misinformation \& disinformation, whether deliberately or accidentally. It is a moral obligation for LIS professionals to raise awareness about misinformation, disinformation, and correct facts, which involves sharing and passing information on social media. As a primary source of fake news, social media is a good place to start. 


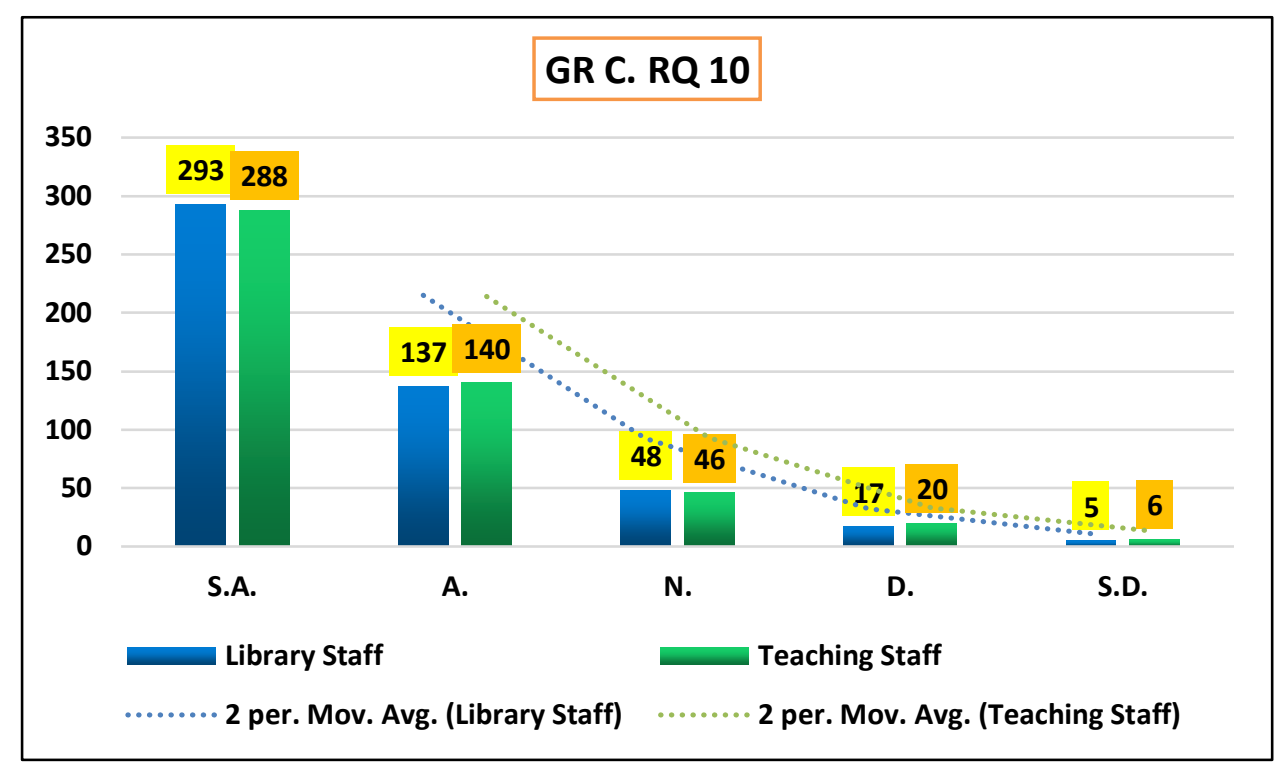

Note: SA- Strongly Agree, A -Agree, N -Neutral, DA- Disagree, SD- strongly Disagree

Figure 12: Regarding Spread Misinformation \& Disinformation without Confirming

The responses displays in figure 12 ensures that majority of LIS professionals (viz, $86 \%$ of library staff \& $85.6 \%$ of teaching staff) accept that they should not post any information on social media without verifying their accuracy.

- RQ 13. I lead a purposeful \& meaningful life being a Library and Information Science Professional

Users are unable to access the physical services available in the library due to the lockdown and closure of institutions. LIS professionals' roles have evolved to include offering e-resources to students and employees, as well as assisting them in completing uninterrupted online studies. Furthermore, LIS professionals help them achieve this goal by providing them with a vast knowledge of online course sites, links of free databases, and other resources.

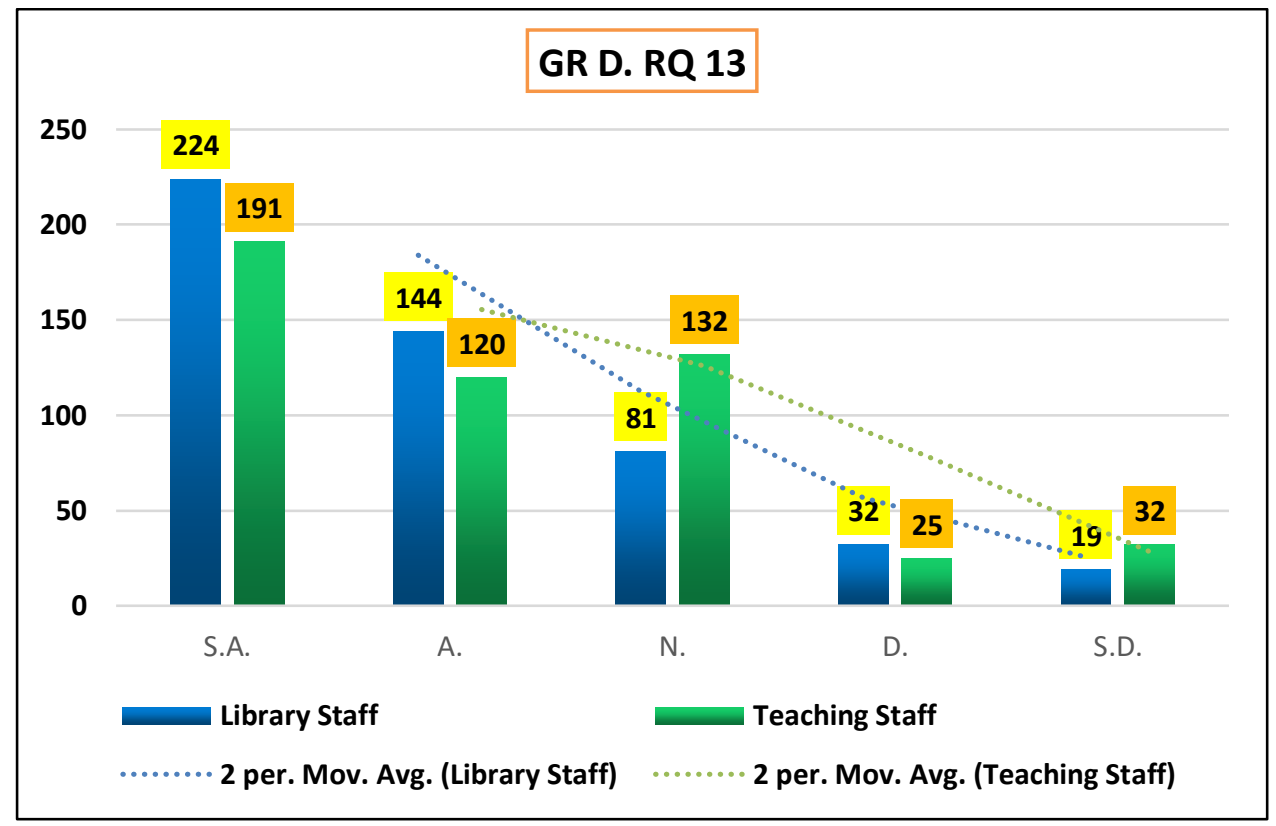

Note: SA- Strongly Agree, A -Agree, N-Neutral, DA- Disagree, SD- strongly Disagree

Figure 13: Lead a Purposeful \& Meaningful life of Being a LIS Professional 
Out of the 500 respondent, $73.6 \%$ (368) of library staff \& $62.2 \%$ (311) of teaching staff ensures that they purposefully \& meaningfully fulfilled the responsibility of a LIS professional. Whereas $16.2 \%$ (81) of library staff \& $26.4 \%$ (132) of teaching staff can complete this responsibility neutrally, but $10.2 \%$ (51) of library staff \& $11.4 \%$ (57) of teaching staff unable to do so.

\section{- RQ 14. I am actively engaged in educating others through webinars or other means of} e-learning

Webinars are trending on academic social networking sites during this lockdown period becoming major source of knowledge sharing among different professionals. LIS professionals are the major part of this educating different people through these webinars whether it's about organizing it or delivering it.

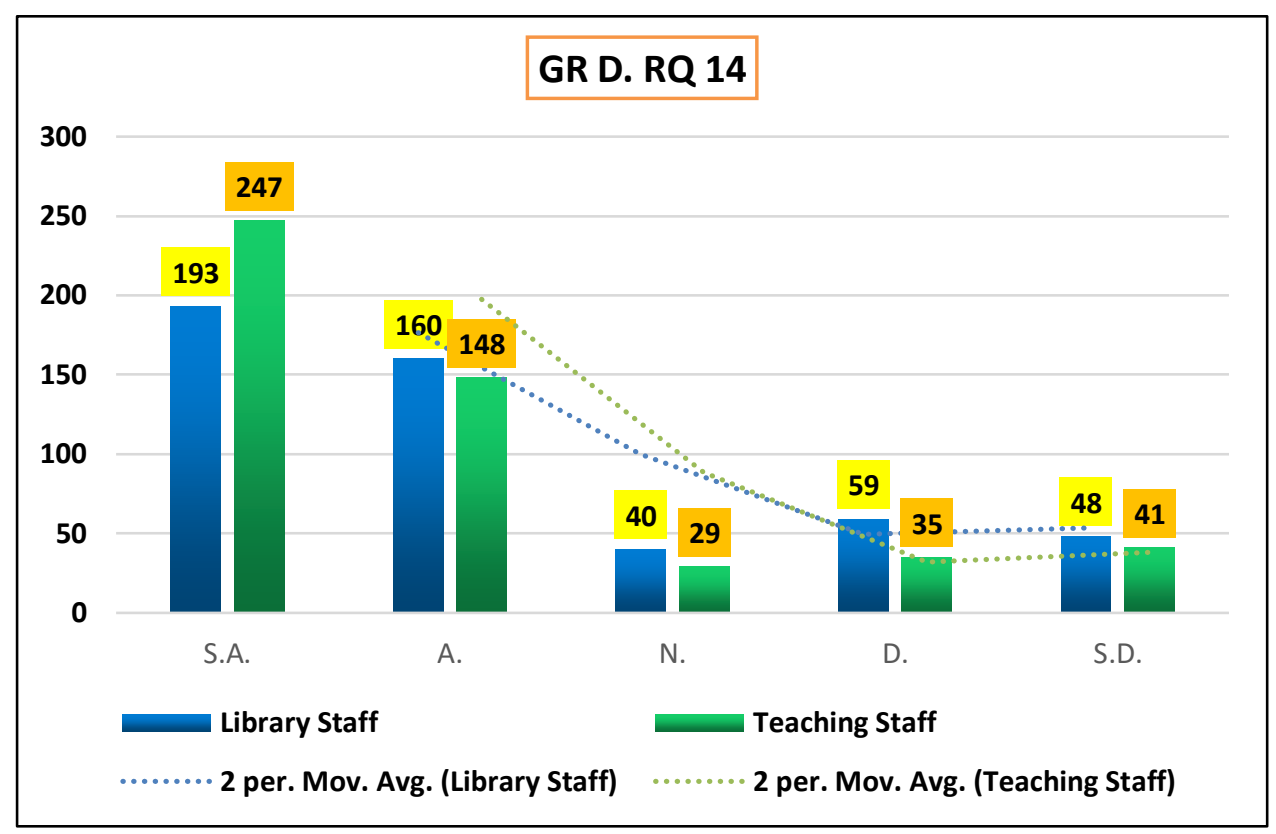

Note: SA- Strongly Agree, A -Agree, N-Neutral, DA- Disagree, SD- strongly Disagree

Figure 14: Regarding Engagement of Educating others \& Spread Awareness

\section{- RQ 15. I am more actively engaged in providing E-resources to patrons.}

This new normal usher in a new age of learning, one in which the traditional learning process is substituted by digital learning. The availability of sufficient e-resources is the most significant prerequisite for this transition. The library staff, as well as teaching staff, will assist patrons in locating suitable online information sources to meet their information needs. 


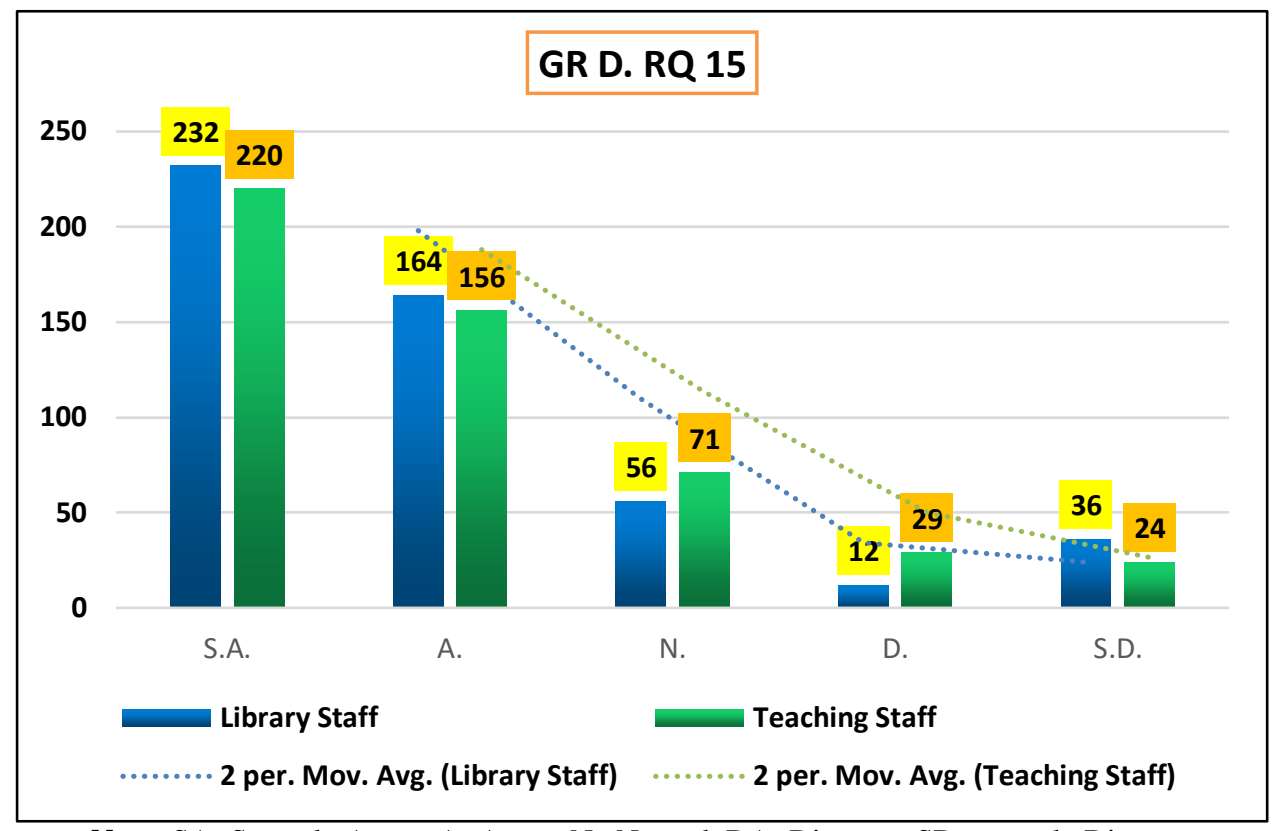

Note: SA- Strongly Agree, A -Agree, N -Neutral, DA- Disagree, SD- strongly Disagree

Figure 15: Engagement regarding Provide e-resources to Patrons

Figure 15 gives information about the responses of the sample respondents in respect to RQ 15. Out of 500 respondents, $79.2 \%$ (396) of library staff $\& 75.2 \%$ of teaching staff positively demand that they actively engaged in providing e-resources to the patrons. In addition, $11.2 \%$ (56) of library staff \& $14.2 \%$ (71) of teaching staff found themself in a neutral position and 9.6\% (48) of library staff \& $10.6 \%$ (53) of teaching staff agreed that they don't involve in above mention procedure.

\section{KEY FINDINGS OF THE STUDY}

1. Study revealed that almost half of the staff are finding it difficult to show interest in daily activities.

2. Impacted heavily on the work-life balance due to lockdown and shift to the digital learning platform.

3. Both the Library \& Teaching staff Library staff tried hard to completing their work-goals and Teaching staff fulfill it with a better performance than Library staff.

4. LIS Professionals became the more active contributor to serve the community during the shift in online education.

5. LIS Professionals actively avoid people sneezing and coughing due to fear of getting infected from COVID-19 which is also causing anxiety problems among employees.

6. Increase in workload affected social and personal relationships of teaching staff more negatively as compared to Library staff.

7. The study also revealed that Library staff suffers more from anxiety may be due to a lack of regular communication and interaction with students and other patrons than the Teaching staff.

8. Many LIS Professionals lost partially or fully income due to the closure of educational institutions, which in return harmed the financial status of employees.

9. During pandemic situations, LIS Professionals lead a meaningful and purposeful life by spreading awareness about misinformation, disinformation and the right information through Webinars.

10. LIS Professionals are actively engaged to provide e-resources to patrons to facilitate teaching-learning during the lockdown.

\section{CONCLUSION}


Due to the alarming rate of rising in COVID-19 cases nationwide, the education system of India has taken a sharp turn towards e-learning, which has changed its dynamic (Agrawal, 2021). The recent pandemic provided an opportunity for pedagogical transition and the adoption of virtual education at all levels of the national education system (Jena, 2020a). It also brought challenges for students, researchers, academicians \& educational institutions in adopting emerging technology in the teaching-learning process. During the pandemic, there has been a significant surge in the usage of virtual tutoring, video conferencing tools, or online learning software (Li \& Lalani, 2020). In this situation, LIS Professionals are boon to combat the needs of students and teachers. Despite their immense effort, unfortunately, the study findings indicate that the performance of LIS professionals imperceptibly hampered due to the negative impact of COVID-19 on their personal efficiency, social relationship, financial situation and physical \& psychological health. Change is inevitable, and LIS professionals should embrace the "new normal" to the best of their abilities, cooperating to address the gaps identified in the study. Although, the present research is limited only to the perceptions of Library staff \& Teaching staff of the field of Library \& Information Science, hence the study deficient with the perception of teaching faculty of other disciplines. Again, the perception of the actual users, i.e. students \& researchers, also missing in the study. They can provide the exact picture of service \& teaching they received from the Library \& Teaching staff and capable of evaluating whether they face any change between before $\&$ during the lockdown period.

\section{REFERENCES}

Agrawal, R. (2021, May 5). Has Covid-19 pandemic brought the need to revisit India's education system? India Today. https://bit.ly/3bc3P0w

AISHE. (2019, August). All India Survey on Higher Education (2018-19). Department of Higher Education, MHRD, Government of India: New Delhi. https://www.education.gov.in/sites/upload_files/mhrd/files/statistics-new/AISHE\%20Final\%2 0Report\%202018-19.pdf

Ali, A., Siddiqui, A. A., Arshad, M. S., Iqbal, F., \& Arif, T. B. (2021). Effects of COVID-19 pandemic and lockdown on lifestyle and mental health of students: A retrospective study from Karachi, Pakistan. Annales Médico-Psychologiques Revue Psychiatrique. https://doi.org/10.1016/j.amp.2021.02.004

Ali, M. Y., \& Gatiti, P. (2020). The COVID-19 (Coronavirus) Pandemic: Reflections on the Roles of Librarians and Information Professionals. Health Information \& Libraries Journal, 37(2). https://doi.org/10.1111/hir.12307

Christian, M., Purwanto, E., \& Wibowo, S. (2020). Technostress Creators on Teaching Performance of Private Universities in Jakarta During Covid-19 Pandemic. Technology Reports of Kansai University, 62(6), 2799-2809. https://www.researchgate.net/publication/343230929

Guha, P., Islam, B., \& Hussain, M. A. (2020). COVID -19 lockdown and penalty of joblessness on income and remittances: A study of inter-state migrant labourers from Assam, India. Journal of Public Affairs. https://doi.org/10.1002/pa.2470

Jena, P. K. (2020a). Impact of Covid-19 on higher education in India. International Journal of Advanced Education and Research, 5(3), 77-81. http://www.alleducationjournal.com/archives/2020/vol5/issue3/5-3-27

Jena, P. K. (2020b). Impact of Pandemic COVID-19 on Education in India. International Journal of Current Research, 12(7), 12582-12586. https://doi.org/10.24941/ijcr.39209.07.2020 
Lep, Ž., Babnik, K., \& Hacin Beyazoglu, K. (2020). Emotional Responses and Self-Protective Behavior Within Days of the COVID-19 Outbreak: The Promoting Role of Information Credibility. Frontiers in Psychology, 11. https://doi.org/10.3389/fpsyg.2020.01846

Li, C., \& Lalani, F. (2020, April 29). The COVID-19 pandemic has changed education forever. This is how. World Economic Forum. https://www.weforum.org/agenda/2020/04/coronavirus-education-global-covid19-online-digit al-learning/

Mertens, G., Gerritsen, L., Duijndam, S., Salemink, E., \& Engelhard, I. M. (2020). Fear of the coronavirus (COVID-19): Predictors in an online study conducted in March 2020. Journal of Anxiety Disorders, 74, 102258. https://doi.org/10.1016/j.janxdis.2020.102258

Migrator. (2000). Advantages and disadvantages of employees working at home. Nibusinessinfo.co.uk. https://www.nibusinessinfo.co.uk/content/advantages-and-disadvantages-employees-workinghome

Purwanto, A., Asbari, M., Fahlevi, M., Mufid, A., Agistiawati, E., Cahyono, Y., \& Suryani, P. (2020). Impact of Work From Home (WFH) on Indonesian Teachers Performance During the Covid-19 Pandemic : An Exploratory Study. International Journal of Advanced Science and Technology, 29(05),

$6235-6244$. http://sersc.org/journals/index.php/IJAST/article/view/15627/7883

Rafiq, M., Batool, S. H., Ali, A. F., \& Ullah, M. (2021). University libraries response to COVID-19 pandemic: A developing country perspective. The Journal of Academic Librarianship, 47(1), 102280. https://doi.org/10.1016/j.acalib.2020.102280

Raj, U. (2020). Indian Education System in Fight against COVID-19 Pandemic. International Journal of Creative Research Thoughts, 8(7), 2084-2088. https://doi.org/10.2139/ssrn.3597340

Robinson, L., \& Smith, M. (2020, April 1). Dealing with Uncertainty During the Coronavirus Pandemic https://www.helpguide.org/articles/anxiety/dealing-with-uncertainty.htm

HelpGuide.org.

Salari, N., Hosseinian-Far, A., Jalali, R., Vaisi-Raygani, A., Rasoulpoor, S., Mohammadi, M., Rasoulpoor, S., \& Khaledi-Paveh, B. (2020). Prevalence of stress, anxiety, depression among the general population during the COVID-19 pandemic: a systematic review and meta-analysis. Globalization and Health, 16(1), 1-11. https://doi.org/10.1186/s12992-020-00589-w

UNESCO. (2020, March 4). COVID-19 Educational Disruption and Response. ; https://en.unesco.org/covid19/educationresponse

Vaidya, P., \& Ali, P. M. N. (2021). Measures and Initiatives Adopted by Indian University Libraries During the COVID-19 Pandemic. In Advances in Library and Information Science (pp. 152172). IGI Global Publisher. https://doi.org/10.4018/978-1-7998-6449-3.ch008 